\title{
Early development and larval behaviour of two clingfishes, Lepadogaster purpurea and Lepadogaster lepadogaster (Pisces: Gobiesocidae)
}

\author{
I. Tojeira • A. M. Faria $\cdot$ S. Henriques $\cdot$ C. Faria $•$ \\ E. J. Gonçalves
}

Received: 26 January 2011 / Accepted: 19 September 2011 /Published online: 8 October 2011

(C) Springer Science+Business Media B.V. 2011

\begin{abstract}
The recent revision on the taxonomic status of Lepadogaster lepadogaster resulted in the division of this species into L. lepadogaster and L. purpurea, the clarification of each species' distribution ranges and the elimination of L. zebrina (now in synonymy with L. lepadogaster). This new taxonomic status led to the need of clarifying the early development of the two species. Embryonic development lasted 21 days in L. purpurea at a mean temperature of $14.2^{\circ} \mathrm{C}$, and 16 days in $L$. lepadogaster at a mean temperature of $16.5^{\circ} \mathrm{C}$. Newly hatched larvae of both species measured $5.2 \mathrm{~mm}$, had the mouth and anus opened,
\end{abstract}

I. Tojeira • A. M. Faria • C. Faria • E. J. Gonçalves $(\bowtie)$

Eco-Ethology Research Unit,

Instituto Superior de Psicologia Aplicada,

R. Jardim do Tabaco 34,

1149-041 Lisboa, Portugal

e-mail: emanuel@ispa.pt

I. Tojeira

Task Group For Maritime Affairs,

R. Costa Pinto 165,

2770-047 Paço de Arcos, Portugal

S. Henriques

Centro de Oceanografia,

Faculdade de Ciências da Universidade de Lisboa,

Campo Grande,

1749-016 Lisboa, Portugal

C. Faria

Centro de Investigação em Educação,

Faculdade de Ciências da Universidade de Lisboa,

Lisboa, Portugal pigmented eyes and almost no yolk. At hatching and throughout development the two species can be distinguished by the ventral pigmentation which is absent in L. purpurea. The change to a benthic mode of life was gradual in both species, with larvae increasingly spending more time close to the bottom until definitely settling. Larval development lasted 33 days in $L$. purpurea at a mean temperature of $14.6^{\circ} \mathrm{C}$ and 18 days in L. lepadogaster at a mean temperature of $16.5^{\circ} \mathrm{C}$. Locomotion and foraging behaviours are described for both species. L. lepadogaster showed a higher frequency of swimming and foraging behaviour when compared with L. purpurea.

Keywords Lepadogaster lepadogaster.

Lepadogaster purpurea - Gobiesocidae · Clingfishes .

Early development $\cdot$ Larval behaviour

\section{Introduction}

Clingfishes are distributed worldwide throughout many different habitats in tropical and temperate seas (Briggs 1955, 1986, 1990). However, knowledge of their behaviour (Gonçalves et al. 1996, 1998) and ecology (Henriques et al. 2002) is extremely poor. This is related to their small size, which enables them to occupy very cryptic microhabitats (Thresher 1984). These species have a ventral sucking disk which provides an extra adaptation to explore crevices, holes and narrow spaces between rocks, as well as to resist 
strong water movements (which are prevalent in the intertidal and shallow subtidal habitats where they occur). Demersal eggs are deposited on the underside of stones, with the male guarding the egg mass which may contain multiple batches at different stages of development (Breining and Britz 2000).

Lepadogaster purpurea (Bonnaterre 1788) and L. lepadogaster (Bonnaterre 1788) are two abundant species of clingfishes (Briggs 1955, 1986). Lepadogaster purpurea ranges from Scotland to Senegal, the Canary and Madeira Islands and the Mediterranean, while L. lepadogaster occurs from as far north as the extreme north-west of Galicia (Spain) to northwest Africa, the Canary and Madeira Islands and the Mediterranean (Henriques et al. 2002). They are very closely-related species, quite similar in their morphology. Adults can be distinguished by the different head marks (or ocelli), as well as the number of the papillae of the sucking disc regions. The different body colouration patterns, the length of the nostrils and the distance between the eyes are other distinctive characters used to identify each species (Henriques et al. 2002). They differ in microhabitat preferences; both species occur in rocky boulder fields of the intertidal and subtidal zones down to about $7 \mathrm{~m}$ of depth, but L. purpurea shelters in larger boulders and can be found in greater depth than L. lepadogaster (Henriques et al. 2002). The most striking difference between these species is however the breeding period. Lepadogaster purpurea breeds mainly during the winter until the beginning of the spring (October to April) and L. lepadogaster breeds mainly during the spring until the beginning of the summer (March to July) (Henriques et al. 2002).

Due to this close resemblance, Lepadogaster lepadogaster was considered until recently one single species with two subspecies: L. lepadogaster lepadogaster and L. lepadogaster purpurea (Henriques et al. 2002). These authors revised the taxonomic status of L. lepadogaster and divided this species into two different ones: L. lepadogaster and L. purpurea. This taxonomic confusion and geographic overlap renders the previously scattered descriptions of the early stages of Lepadogaster (Guitel 1888) useless and clarification is needed in order to correctly ascribe the right larvae to the right species.

The objective of this study is therefore to clarify the early development of $L$. lepadogaster and $L$. purpurea providing a detailed description of the embryonic and larval stages. The early ontogeny of locomotor and foraging behaviours is also described.

\section{Materials and methods}

Fourteen specimens of L. purpurea were captured in January and February 2006, and fourteen specimens of L. lepadogaster were captured in April 2006 at Alpertuche beach $\left(38^{\circ} 28^{\prime} \mathrm{N} ; 8^{\circ} 59^{\prime} \mathrm{W}\right)$ located at the Arrábida Marine Park (Portugal), during the breeding season of each species. Individuals were kept in a 2501 tank illuminated with fluorescent light $(60 \mathrm{~W})$ $12 \mathrm{~h}$ per day and were fed twice a day with a varied diet (shrimps, clams, cockles and mussels). Water temperature was kept at $13^{\circ} \mathrm{C}$ for L. purpurea and $15^{\circ} \mathrm{C}$ for L. lepadogaster, according to the sea temperature at the sampling site. The substratum included several layers of sand, with small $(5-10 \mathrm{~cm})$ and large $(20$ $30 \mathrm{~cm}$ ) stones. Shelter was formed by flat rocks that were also used as breeding sites by the males.

For each species, eight batches were obtained. The complete embryonic development sequence for $L$. purpurea was based on a batch laid on 17 March $2006\left(\right.$ mean \pm S.D water temperature $=14.2 \pm 0.7^{\circ} \mathrm{C}$, range $=13-15^{\circ} \mathrm{C}, n=20$ ) and for $L$. lepadogaster on two batches laid on 1 June 2006 (mean \pm S.D. water temperature $=16.50 \pm 0.46^{\circ} \mathrm{C}$, range $=16-17^{\circ} \mathrm{C}, n=16$ ) and 11 June $2006($ mean \pm S.D. water temperature $=$ $16.50 \pm 0.43^{\circ} \mathrm{C}$, range $=16-17^{\circ} \mathrm{C}, n=16$ ). The remaining batches were used to complete descriptions, confirm specific developmental features, and validate the sequence and timing of events and were not sampled on a daily basis. No differences in the sequence and timing of events between these batches and the ones used for descriptions were found. Eggs were collected daily, the egg capsules were opened and the embryos distended to allow detailed observations. Mean number of eggs per batch, egg density and egg mass area was calculated for each species.

The larval development sequence was described based on two batches for each species. For L. purpurea, batches hatched on 6 February 2006 (mean \pm S.D. water temperature $=14.60 \pm 0.54^{\circ} \mathrm{C}$, range $=13-15^{\circ} \mathrm{C}, n=39$ ) and 3 March 2006 (mean \pm S.D. water temperature $=$ $14.80 \pm 1.68^{\circ} \mathrm{C}$, range $=13-23^{\circ} \mathrm{C}, n=32$ ), and for $L$. lepadogaster batches hatched on 13 May 2006 $\left(\right.$ mean \pm S.D. water temperature $=17.80 \pm 0.32^{\circ} \mathrm{C}$, range $\left.=17-18^{\circ} \mathrm{C}, n=34\right)$ and on 1 June 2006 (mean \pm 
S.D. water temperature $=17.10 \pm 0.43^{\circ} \mathrm{C}$, range $=16-$ $\left.18^{\circ} \mathrm{C}, n=33\right)$. Upon hatching, larvae were collected by aspiration from the parental aquarium and reared in 251 tanks illuminated with fluorescent light $(15 \mathrm{~W})$ $24 \mathrm{~h}$ per day. A constant flow of seawater was maintained. Larvae were fed twice a day with a mixture of Brachionus sp. and Artemia sp. nauplii $(2,040$ individuals per $600 \mathrm{ml})$ and microalgae. During the first three days after hatching, decapsulated eggs of Artemia sp. were added to the mixture. Larvae were collected daily until metamorphosis.

Both eggs and larvae (after having been anesthetized with MS-222) were observed under a Nikon SMZ-800 stereomicroscope, photographed with a Nikon Coolpix 5400 camera and preserved in 4\% saline formalin buffered with sodium borate. All larval measurements correspond to standard length $\left(L_{\mathrm{S}}\right)$.

In addition to embryonic and larval descriptions, behavioural observations were conducted on a daily basis from day 1 to day 17 post hatching for $L$. purpurea, and from day 1 to day 20 post hatching for L. lepadogaster. Larval behaviours were categorized into modal action patterns (MAPs) (Table 1). A modal action pattern is defined as a spatiotemporal pattern of coordinated movement in which the pattern clusters around some mode making the behaviour recognizable (Barlow 1968). During observations aeration was stopped in order to avoid the influence of turbulence on larval behaviour. The focal animal technique (Martin and Bateson 1993) was used to observe a randomly selected larva for a 1-min interval. This was done for a total of ten larvae per day. During each observation period, the occurrence of seven modal action patterns, grouped into three classes was recorded (Table 1). Locomotory and non-directed behaviours were recorded as time variables, whereas foraging behaviours were recorded as frequency variables.

A one way analysis of variance (ANOVA) was used to test for differences between species in each of the three classes of MAPs (locomotory, nondirected, and foraging). Prior to statistical analysis, the data were checked for homogeneity of variances (F-max test) and distribution normality (ShapiroWilk's W test).

\section{Results}

Embryonic development

Both species laid the egg masses in a single layer underneath the rocks, with $L$. purpurea preferring larger stones. Generally, the male provided all parental care, fanning and rubbing the eggs until hatching. Newly laid eggs of both species were bright yellow; however eggs turned orange towards the end of development. They were oval in shape, with a lower flattened surface containing fine filaments for attachment to the rocks (Fig. 1 (a), (b)). Egg diameter was significantly different between the two species $($ mean \pm S.D. $=1.80 \pm 0.04 \mathrm{~mm}$, range $=1.70-1.90, n=$ 53 for $L$. purpurea and mean \pm S.D. $=1.90 \pm 0.03 \mathrm{~mm}$, range $=1.80-1.90, n=46$ for $L$. lepadogaster; $t$-test: $t=$ $-2.35, \mathrm{df}=34, p<0.05)$. For L. purpurea, mean $( \pm \mathrm{S}$. D.) batch area was $4.19 \pm 1.36 \mathrm{~cm}^{2}$ (range $=1.94-5.18$,

Table 1 Definition of modal action patterns [MAPs - after Barlow (1968)] observed in developing Lepadogaster larvae

\begin{tabular}{ll}
\hline MAP & Definition \\
\hline $\begin{array}{l}\text { Locomotory } \\
\text { Swim }\end{array}$ & Forward movement of the larva through the water column using tail beats \\
Pause-Travel & Larvae scans for prey; if prey is not located it moves a short distance, stops, and scans again \\
Non-directed & \\
Pause & Larva is motionless and stationary in the water column \\
Sink & Larva is motionless and descends through the water column, usually head first \\
Foraging & \\
Orientation & The head is directed towards a prey item \\
Fixate & The larva is stationary and bends its body into an "S" shape position; typically follows orient \\
Lunge & The larva moves towards the prey item from the fixate position in an attempt to capture it \\
\hline
\end{tabular}



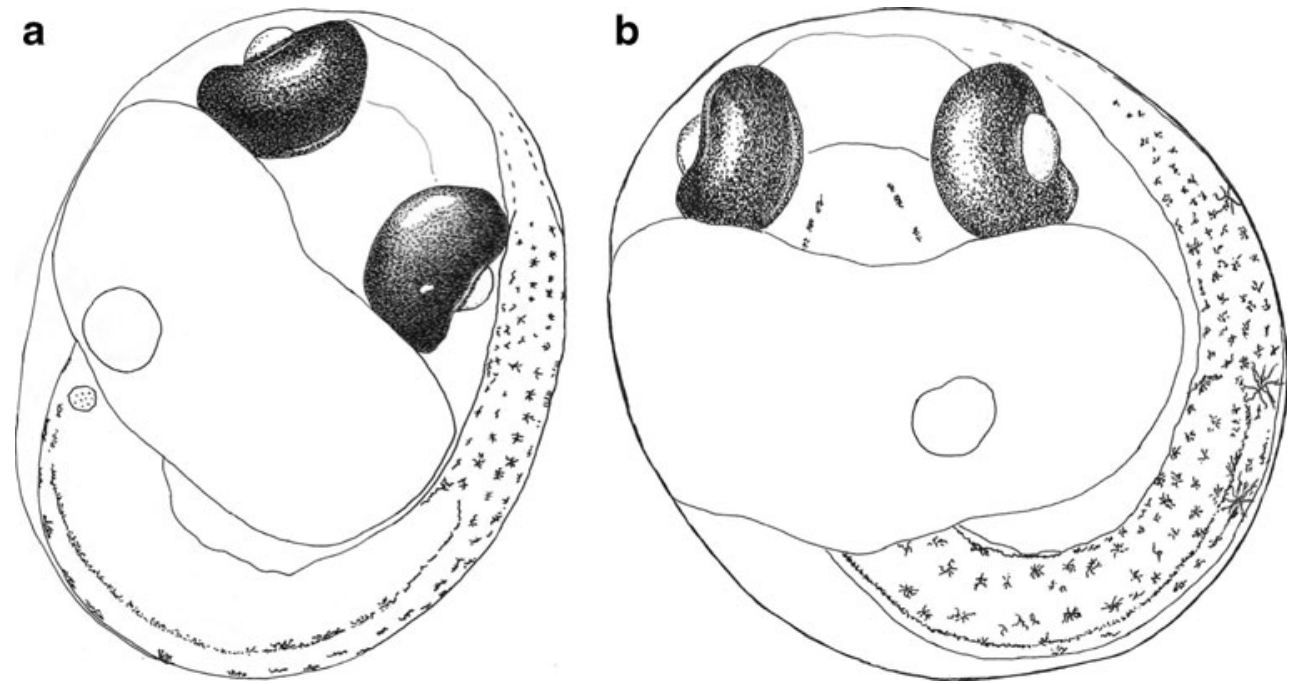

Fig. 1 (a) Dorsal view of the embryo of Lepadogaster purpurea and (b) Lepadogaster lepadogaster

$n=6)$, mean ( \pm S.D.) number of eggs per batch was $144.40 \pm 46.46$ eggs $($ range $=60.10-177.10, n=6)$ and mean ( \pm S.D.) egg density was $34.50 \pm 3.39$ eggs.cm ${ }^{-2}$ (range $=31.00-39.00, n=6$ ). For L. lepadogaster, mean ( \pm S.D.) batch area was $4.61 \pm 2.46 \mathrm{~cm}^{2}$ (range $=1.84-8.60, n=7)$, mean $( \pm$ S.D.) number of eggs per batch was $123.10 \pm 53.74$ eggs (range $=44.16-$ $176.70, n=7)$ and mean ( \pm S.D.) egg density was $27.71 \pm 4.27$ eggs.cm ${ }^{-2}$ (range $\left.=22.00-32.00, n=7\right)$.

Embryonic development lasted 21 days in $L$. purpurea (mean \pm S.D. water temperature $=14.20 \pm$ $0.67^{\circ} \mathrm{C}$, range $=13-15^{\circ} \mathrm{C}, n=20$ ) and 16 days in $L$. lepadogaster $($ mean \pm S.D. water temperature $=16.50 \pm$ $0.46^{\circ} \mathrm{C}$, range $=16-17^{\circ} \mathrm{C}, n=16$ ). The main ontogenetic events of embryonic development for each species are shown in Table 2. Embryos of both species had a non-segmented yolk, consisting of a large oil droplet surrounded by several small ones.

Circulation of the blood fluid was first registered on day 9 in $L$. purpurea, and on day 6 in $L$. lepadogaster. Pigmentation first appeared in the eyes, followed by the lateral side of the body. In $L$. purpurea, round melanophores started to cover the middle region, then spread to the anterior and posterior body areas (cephalic and caudal areas). These round melanophores changed into star shaped melanophores throughout development. In L. lepadogaster, star shaped melanophores started to cover both the lateral side of the body and the caudal region until the end of the myomeres, spreading to the cephalic region in the following days.
The major difference between the embryos of these two species was the absence or residual pigmentation in the ventral fin fold region of L. purpurea (Fig. 1 (a)), which clearly contrasted with the strong pigmentation due to the star shaped melanophores in the gut ventral region in L. lepadogaster (Fig. 1 (b)). Three star shaped melanophores, which became ramified until hatching, were also present in the lower jaw of L. lepadogaster (Fig. 1 (b)) but absent in L. purpurea. Near hatching, movements of the embryos increased, in particular eye movements. Hatching of the entire batches occurred throughout a 2-day period. Larvae of both species hatched with the head first and immediately swam to the surface where they seemed to gulp air, probably to fill the gas bladder. Figure 2 shows larvae collected at different developmental stages and Table 3 presents the main ontogenetic events of larval development for both species.

\section{Larval development}

Newly hatched larvae of both species measured on average $5.20 \pm 0.08 \mathrm{~mm}$ (mean \pm S.D.) (range $=5.00$ $5.30 \mathrm{~mm}, n=5$ for $L$. purpurea; range $=5.20$ $5.30 \mathrm{~mm}, n=5$ for L. lepadogaster) and hatched with the mouth and anus opened, lips and jaws differentiated, eyes completely formed and fully pigmented, the nostrils opened and the yolk almost fully absorbed (Fig. 2 (a-I), (b-I)). The opercula were open, with three branchial arches present; the characteristic nostril tentacles of adult fishes were not yet 


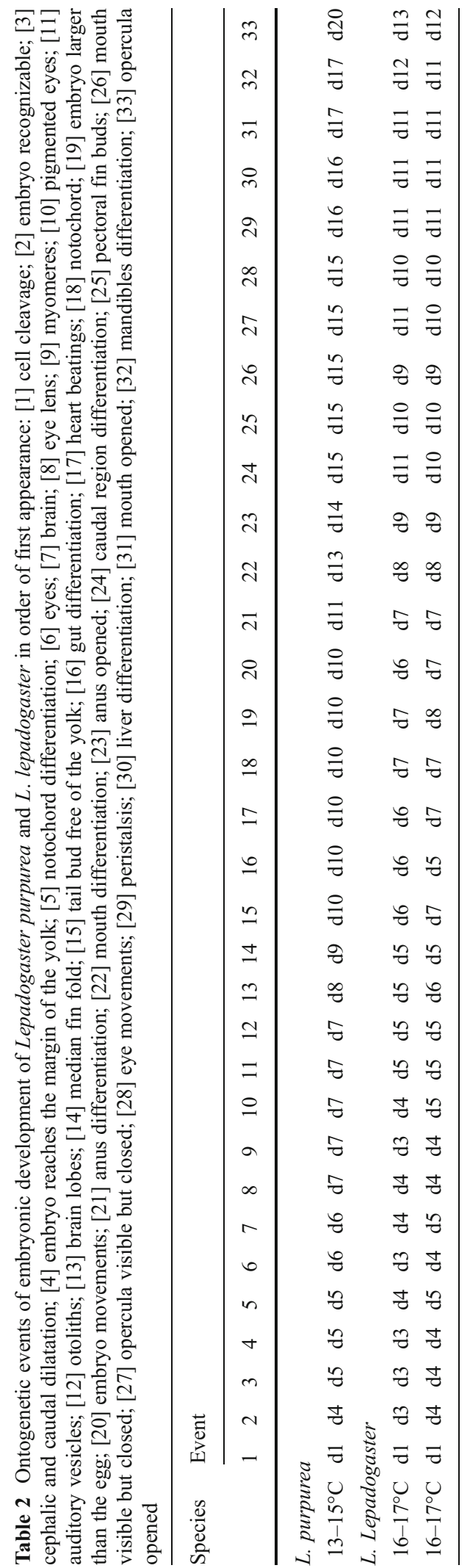
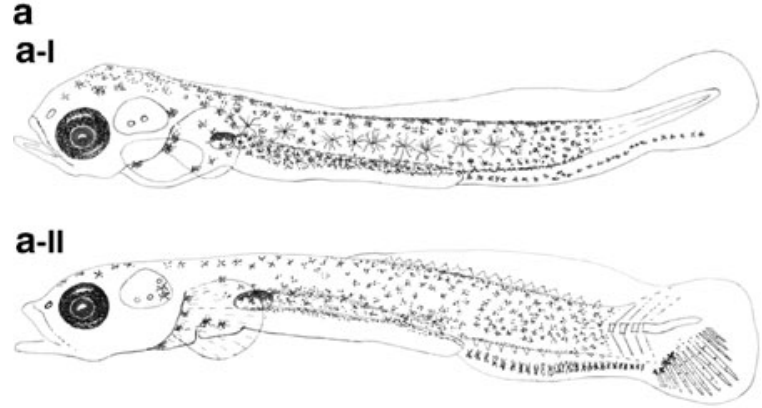

a-III

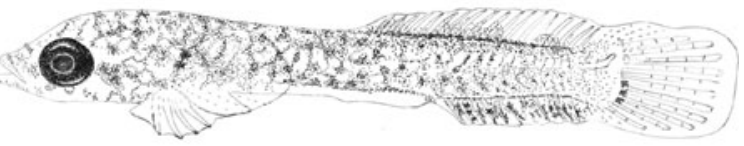

b
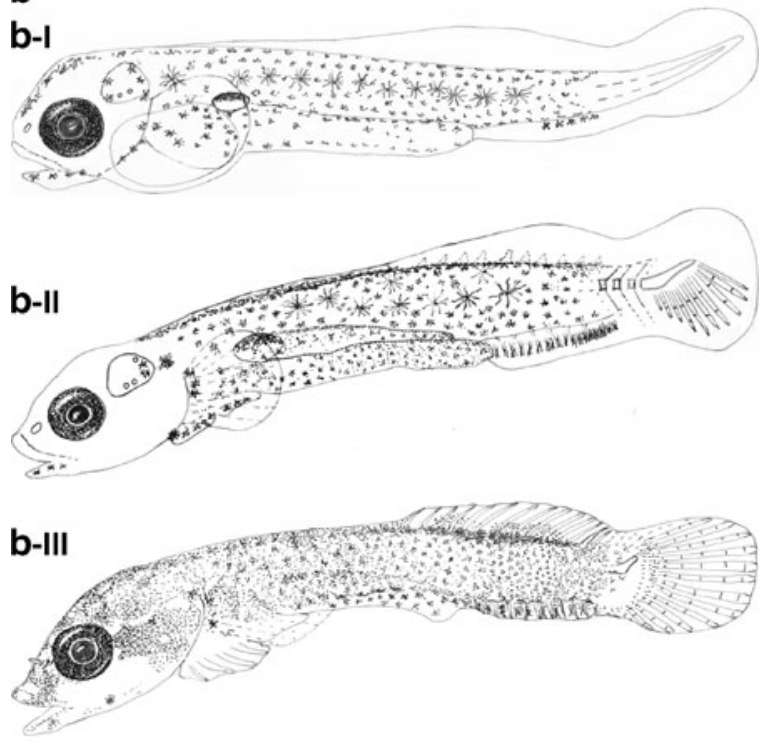

Fig. 2 (a) Larvae of Lepadogaster purpurea and (b) Lepadogaster lepadogaster collected at different development stages: (I) newly hatched larva, (II) post-flexion larva with the caudal fin rays differentiated and with anal and second dorsal fin rays starting to develop, (III) juvenile

developed; the liver and the heart were completely formed and the blood circulation was noticeable. Larvae hatched with both pectoral fins differentiated but without any rays and with the median fin fold ranging from the cephalic area to the anus.

Pigmentation patterns were quite similar (with few exceptions) and changed throughout development. Both larvae were strongly pigmented at the time of hatching, with two parallel rows in the dorsal area composed of $c a .30$ ramified melanophores in $L$. purpurea and 26 in L. lepadogaster, which covered 
Table 3 Ontogenetic events of larval development of $L$. purpurea and L. lepadogaster in order of first appearance (days after hatching): [1] filled gas bladder; [2] yolk absorption; [3] exogenous feeding; [4] caudal fin rays; [5] pectoral fin rays; [6] notochord starts to flex; [7] ventral disk differentiation; [8] larvae started to settle; [9] dorsal fin rays; [10] anal fin rays;
[11] ossified vertebra; [12] teeth; [13] notochord flexion completed; [14] all larvae settled; [15] median fin fold reabsorption; [16] tentacles differentiation; [17] juvenile typical pigmentation. Size ranges are shown for the main ontogenetic stages

\begin{tabular}{|c|c|c|c|c|c|c|c|c|c|c|c|c|c|c|c|}
\hline \multirow[b]{2}{*}{ Species } & \multicolumn{15}{|c|}{ Event } \\
\hline & 12 & 4 & 5 & 6 & 7 & 8 & 9 & 10 & 11 & 12 & 13 & 14 & 15 & 16 & 17 \\
\hline \multicolumn{16}{|l|}{ L. purpurea } \\
\hline \multirow{2}{*}{$13-15^{\circ} \mathrm{C}$} & $\begin{array}{lll}\mathrm{d} 1 & \mathrm{~d} 2 & \mathrm{~d} 2\end{array}$ & $\mathrm{~d} 8$ & d9 & d12 & $\mathrm{d} 12$ & $\mathrm{~d} 13$ & $\mathrm{~d} 25$ & $\mathrm{~d} 25$ & $\mathrm{~d} 27$ & d30 & $\mathrm{d} 30$ & $\mathrm{~d} 33$ & d33 & d39 & d39 \\
\hline & $5.4-7.3 \mathrm{~mm}$ & \multicolumn{4}{|c|}{$7.4-8.3 \mathrm{~mm}$} & & \multicolumn{5}{|c|}{$8.4-9.3 \mathrm{~mm}$} & \multicolumn{4}{|c|}{$9.4>10 \mathrm{~mm}$} \\
\hline \multirow{2}{*}{$13-23^{\circ} \mathrm{C}$} & d1 $\quad$ d2 $\quad$ d2 & d9 & d9 & d11 & d11 & d13 & $\mathrm{d} 25$ & $\mathrm{~d} 25$ & $\mathrm{~d} 26$ & $\mathrm{~d} 26$ & $\mathrm{~d} 28$ & $\mathrm{~d} 27$ & $\mathrm{~d} 31$ & $\mathrm{~d} 32$ & $\mathrm{~d} 32$ \\
\hline & $5.4-7.3 \mathrm{~mm}$ & \multicolumn{5}{|c|}{$7.4-8.3 \mathrm{~mm}$} & \multicolumn{5}{|c|}{$8.4-9.3 \mathrm{~mm}$} & \multicolumn{4}{|c|}{$9.4>10 \mathrm{~mm}$} \\
\hline \multirow[t]{2}{*}{ L. Lepadogaster } & & & & & & & & & & & & & & & \\
\hline & d1 $\quad$ d1 & $\mathrm{d} 4$ & d5 & d6 & d6 & d7 & d11 & d11 & $\mathrm{d} 13$ & $\mathrm{~d} 14$ & d17 & $\mathrm{d} 18$ & d19 & $\mathrm{d} 20$ & d 25 \\
\hline $16-18^{\circ} \mathrm{C}$ & $5.4-6.3 \mathrm{~mm}$ & \multicolumn{2}{|c|}{$6.4-7.0 \mathrm{~mm}$} & \multicolumn{6}{|c|}{$7.1-8.3 \mathrm{~mm}$} & \multicolumn{6}{|c|}{$8.4-9.3 \mathrm{~mm}$} \\
\hline \multirow{2}{*}{$17-18^{\circ} \mathrm{C}$} & $\begin{array}{lll}\text { d1 } & \text { d1 } & \text { d1 }\end{array}$ & $\mathrm{d} 5$ & $\mathrm{~d} 5$ & $\mathrm{~d} 6$ & $\mathrm{~d} 6$ & $\mathrm{~d} 10$ & $\mathrm{~d} 11$ & d11 & $\mathrm{d} 16$ & $\mathrm{~d} 17$ & $\mathrm{~d} 14$ & $\mathrm{~d} 15$ & $\mathrm{~d} 15$ & $\mathrm{~d} 15$ & d19 \\
\hline & $5.4-6.9 \mathrm{~mm}$ & \multicolumn{4}{|c|}{$7.0-8.9 \mathrm{~mm}$} & \multicolumn{3}{|c|}{$9.0-9.9 \mathrm{~mm}$} & \multicolumn{7}{|c|}{$10.0-11.2 \mathrm{~mm}$} \\
\hline
\end{tabular}

the pre- and post-anal area until the last 4-6 myomeres. In the lateral trunk, ramified melanophores were distributed from the post-opercular area, forming a V-pattern coincident with the myomeres, until the last 4-6 myomeres. In the ventral trunk, there were $c a .12$ ramified melanophores in $L$. purpurea and eight in L. lepadogaster. Close to the urostyle, two round melanophores were present in both species. On the ventral area of the median fin fold there were ca. 30 star-shaped melanophores in $L$. purpurea and 21 in L. lepadogaster. The gut region was heavily pigmented on both the dorsal and lateral sides, with ramified melanophores. In L. purpurea, the anus was fully surrounded by melanophores while in L. lepadogaster, melanophores agglomerated near the anus but did not surround it. The gas bladder had a distinct dorsal pigmentation in both species. Similarly to what was observed for the embryos, the most noticeable difference between species was the absence or residual ventral pigmentation in the gut region of L. purpurea, while in L. lepadogaster more than 30 ramified melanophores were present in the gut ventral region. On the base of the pectoral fin there were two melanophores in L. purpurea and three in L. lepadogaster. On the dorsal cephalic area, larvae of both species had three major sets of ramified melanophores organised in the following pattern (counting from the tip of the nose to the post-ocular area): $4+11+13$ in L. purpurea and $4+9+7$ in $L$. lepadogaster. On the median head, behind the opercula, there were ca. 10 ramified melanophores in both species. Inside the internal otic vesicles, from a dorsal view, there were two melanophores visible in L. purpurea and four in L. lepadogaster. A single punctiform melanophore on the gular region, as well as two ramified melanophores in the throat region (four in the inferior lip and one in the opercula), were present in L. lepadogaster but absent in L. purpurea.

In $L$. purpurea, three ramified melanophores appeared in a row in the post-anal lateral side above the notochord on day $4(6.7-7.3 \mathrm{~mm})$. These pigments disappeared later in development at day 10 $(7.8-8.3 \mathrm{~mm})$. At day $12(8.0-8.3 \mathrm{~mm})$, the notochord flexion started, the ventral disc (modification of the pelvic fins) started to differentiate and the larval body became less pigmented, with the exception of the starshaped melanophores in the anal median fold and in the cephalic region [Fig. 2 (a-II)]. At day 33 (9.4$9.5 \mathrm{~mm}$ ), all individuals were settled and acquired a benthic life style, and fin rays were formed: $\mathrm{D}=17$ (17-21); $\mathrm{C}=11$ (11-14); $\mathrm{A}=11$ (10-12); $\mathrm{P}=21$ (2023). Larvae begun slowly to metamorphose and pigmentation started to become similar to the adult fish. By day $39(9.5-10 \mathrm{~mm})$ the nostril tentacles were already formed.

In L. lepadogaster, a regression on the expansion of the melanophores in the lateral region was registered at day $6(7.1-7.3 \mathrm{~mm})$, coinciding with 
the notochord flexion, and the ventral disc started to develop [Fig. 2 (b-II)]. At day 13 (8.0-8.3 mm), seven ramified melanophores were noticeable in the anterior, medium and posterior area of the ventral disc region. Larva started to make contact with the bottom of the aquarium at day 7 and by day $18(8.4-9.3 \mathrm{~mm})$ all larvae were settled. At this time, all fin rays were formed: $\mathrm{D}=17$ (17-21); $\mathrm{C}=12$ (11-14); $\mathrm{A}=11$ (1012); $\mathrm{P}=21(20-23)$, and the nostril tentacles begun to differentiate.

Juvenile pigmentation started to appear after settlement (Fig. 2 (a-III), (b-III)). In both species, the eyes were silver with some pale red and orange colours, the head was carmine with some whitish spots and the body was heavily pigmented with carmine-orange pigments. In L. purpurea, the unpigmented ventral region started to acquire a pinkish shade. Both species presented three sets of melanophores in the cephalic region (from the tip of the nose to the post-ocular area: $2+11+13$ ) and three ramified melanophores could be distinguished on the base of the pectoral fin. In L. purpurea, three melanophores were present at the base of the dorsal fin between the 1 st, 3rd and 5th rays; the caudal fin had two ramified melanophores between the $3 \mathrm{rd}$ and 5 th rays and 1 ramified melanophore at the end of the notochord; a single melanophore in the anterior area of the sucking disc, two in the median area and one in the posterior area were characteristic at this stage. In L. lepadogaster, three star shaped melanophores were present in the caudal fin region at day $21(8.3-8.5 \mathrm{~mm})$. These were the same melanophores that were visible at the end on the notochord before flexion started. The dorsal region of the gut was heavily pigmented and in the anus opening there was a set of melanophores. In the ventral area of the gut, two rows of ramified melanophores were also distinguished. Only the base of the dorsal and anal fins was pigmented with the

Table 4 Comparison of the main developmental aspects between the two species during the embryonic, larval and juvenile stages

\begin{tabular}{|c|c|c|c|}
\hline & Embryos & Larvae & Juveniles \\
\hline \multirow[t]{5}{*}{ L. purpurea } & $\begin{array}{l}\text { Absence or residual } \\
\text { pigmentation in the } \\
\text { ventral fin fold region }\end{array}$ & $\begin{array}{l}\text { Melanophores surrounding } \\
\text { the anus }\end{array}$ & $\begin{array}{l}\text { The unpigmented ventral region } \\
\text { start to acquire a pinkish shade }\end{array}$ \\
\hline & $\begin{array}{l}\text { Absence of pigmentation } \\
\text { in the lower jaw }\end{array}$ & $\begin{array}{l}\text { Absence or residual } \\
\text { pigmentation in the gut region }\end{array}$ & $\begin{array}{l}3 \text { melanophores at the base of the } \\
\text { dorsal fin (between the } 1 \mathrm{st}, 3 \mathrm{rd} \\
\text { and } 5 \text { th rays) }\end{array}$ \\
\hline & & $\begin{array}{l}\text { Absence of pigmentation in the } \\
\text { lower jaw }\end{array}$ & $\begin{array}{l}2 \text { ramified melanophores in the } \\
\text { caudal fin (between the 3rd } \\
\text { and } 5 \text { th rays) }\end{array}$ \\
\hline & & & $\begin{array}{l}1 \text { ramified melanophore at the end } \\
\text { of the notochord }\end{array}$ \\
\hline & & & $\begin{array}{l}1 \text { melanophore in the anterior area } \\
\text { of the sucking disc, } 2 \text { in } \\
\text { the median area and } 1 \text { in the } \\
\text { posterior area }\end{array}$ \\
\hline \multirow[t]{5}{*}{ L. lepadogaster } & $\begin{array}{l}\text { Strong pigmentation of star } \\
\text { shaped melanophores in the } \\
\text { gut ventral region }\end{array}$ & $\begin{array}{l}\text { Melanophores agglomerate near } \\
\text { the anus but do not surround it }\end{array}$ & $\begin{array}{l}3 \text { star melanophores in the } \\
\text { caudal fin region }\end{array}$ \\
\hline & $\begin{array}{l}3 \text { star shaped melanophores } \\
\text { (became ramified in the } \\
\text { end of development) } \\
\text { present in the lower jaw }\end{array}$ & $\begin{array}{l}\text { More than } 30 \text { ramified } \\
\text { melanophores in the gut region }\end{array}$ & $\begin{array}{l}\text { A set of melanophores at the anus } \\
\text { opening }\end{array}$ \\
\hline & & $\begin{array}{l}1 \text { punctiform melanophore on the } \\
\text { gular region }\end{array}$ & $\begin{array}{l}2 \text { rows of ramified melanophores } \\
\text { in the ventral area of the gut }\end{array}$ \\
\hline & & $\begin{array}{l}2 \text { ramified melanophores in the } \\
\text { throat region ( } 4 \text { in the inferior } \\
\text { lip and } 1 \text { in the opercula) }\end{array}$ & $\begin{array}{l}\text { Base of dorsal and anal fins } \\
\text { heavily pigmented }\end{array}$ \\
\hline & & & $\begin{array}{l}\text { Anal fin with star shaped } \\
\text { melanophores }\end{array}$ \\
\hline
\end{tabular}


Fig. 3 Mean proportion of time Lepadogaster purpurea (closed symbols) and Lepadogaster lepadogaster (open symbols) larvae spent performing total locomotory (triangles), total non-directed (circles) and total foraging (squares) MAPs throughout development

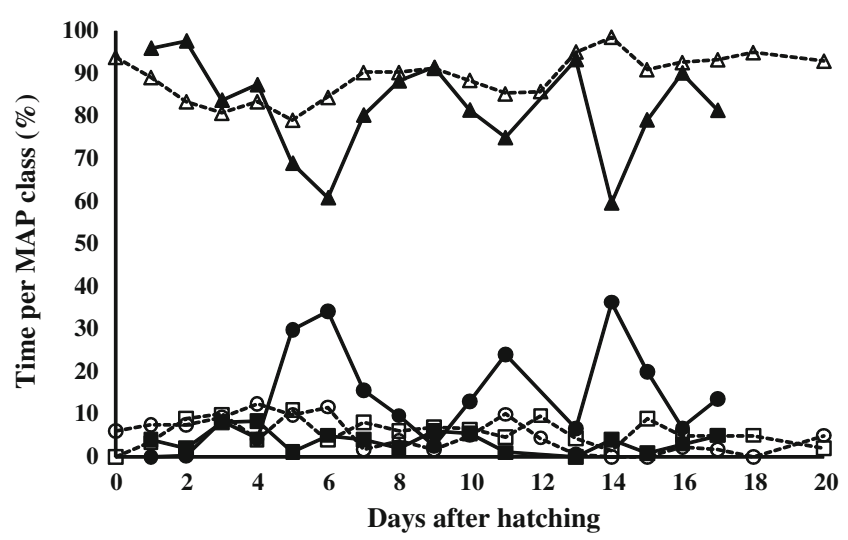

foraging MAPs (ANOVA, d.f. $=34, F=4.48, P=0.04$ ) (Fig. 6). In both species, orientation to the prey was always followed by fixation; however, the frequency of attacks (lunge MAP) was lower since attack did not always followed orientation and fixation behaviours.

\section{Discussion}

Close resemblances between the gobiesocids Lepadogaster lepadogaster and Lepadogaster purpurea lead to taxonomic confusion that needed a clarification, especially at the embryonic and larval stages. In L. purpurea the mean length of the long axis of the eggs was $1.8 \mathrm{~mm}$ and $1.9 \mathrm{~mm}$ in L. lepadogaster, which agrees with the available descriptions on other gobiesocids (Allen 1984; Hefford 1910; Padoa 1956; Russel 1976). However, Breining and Britz (2000) report smaller lengths for L. lepadogaster, ranging from 1.5 to $1.8 \mathrm{~mm}$. According to several authors, the number of eggs per clutch can vary in the wild from 200 to 250 (Allen 1984; Russel 1976), or up to 300
Fig. 4 Mean proportion of time Lepadogaster purpurea (closed symbols) and Lepadogaster lepadogaster (open symbols) larvae spent performing locomotory MAPs (swim-triangles; pause-travel-circles) throughout development

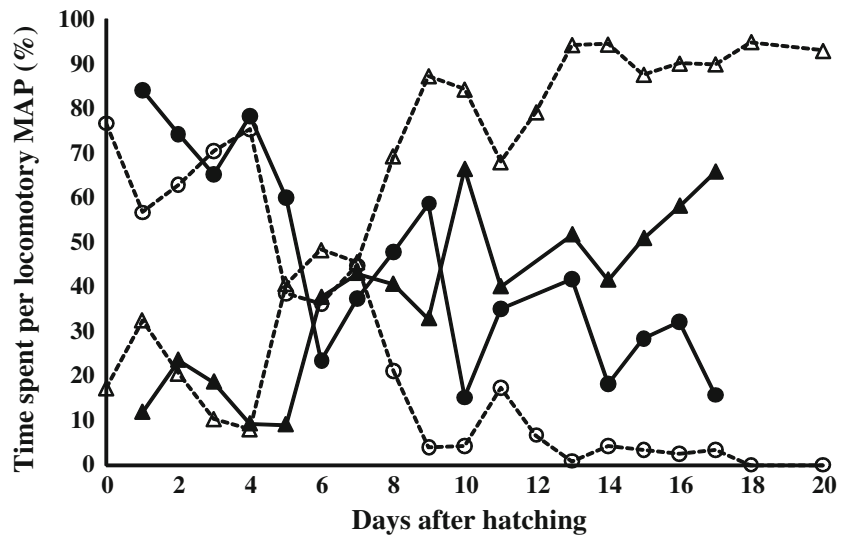


Fig. 5 Mean proportion of time Lepadogaster purpurea (closed symbols) and Lepadogaster lepadogaster (open symbols) larvae spent performing non-directed MAPs (pause - triangles; sink-circles) throughout development

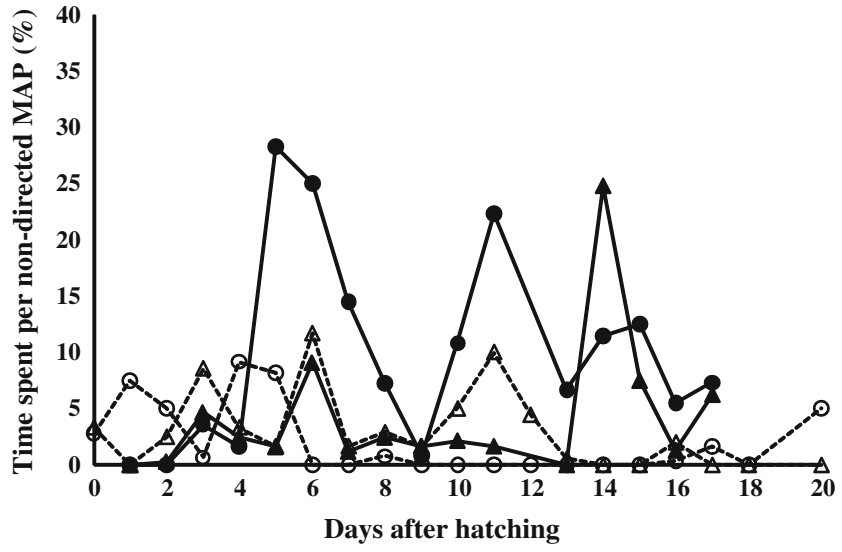

species can be easily distinguished from those of $L$. candolii (the only other species of the genus) which are considerable less pigmented (Guitel 1888; Russel 1976; Allen 1984).

The change to a benthic mode of life was gradual in both species, with larvae increasingly spending more time close to the bottom until definitely settling. Larval development lasted 18 days in L. lepadogaster and approximately 30 days in L. purpurea. Different results could however be expected if larvae were reared alternating light and dark conditions. Nevertheless, the light:dark regime used did not seem to have induce relevant changes in the duration of the larval period of $L$. lepadogaster, since the pelagic larval duration of reared larvae was well within the values reported for wild larvae (range $=11-18$ days; Beldade et al. 2007) and other spring-spawners temperate gobiesocids (e.g. Apletodon dentatus $=15$ days, Gouania wildenowi $=$ 17 days, Lepadogaster candollei $=13$ days; Raventós and Macpherson 2001). There are however no data
Fig. 6 Frequency of orient (triangles) and lunge (circles) MAPs of Lepadogaster purpurea (closed symbols) and Lepadogaster lepadogaster (open symbols) larvae throughout development

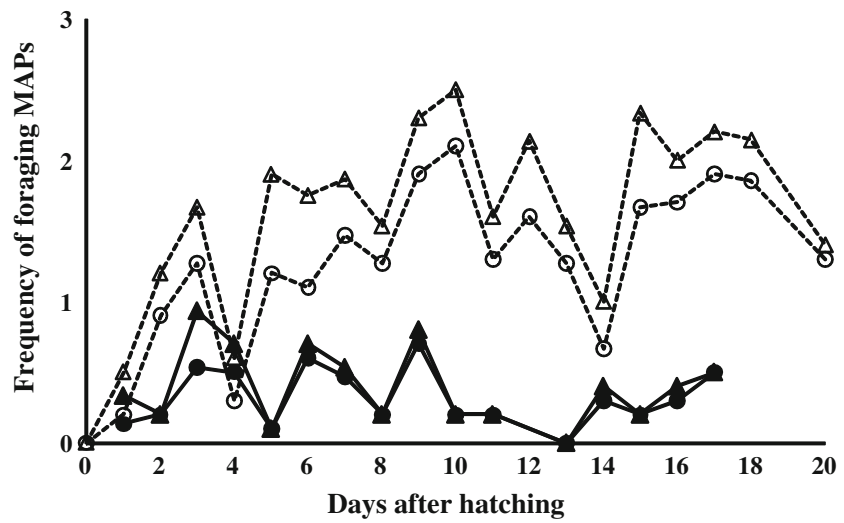


available for wild L. purpurea larvae or other winterspawner gobiesocids, and therefore a word of caution is needed since photoperiod may affect growth rates and pelagic larval durations. These differences in larval development are relevant for species that hatch with the same size and similar morphologies and may be explained by the striking difference in the breeding periods of the two species. The lower water temperature in the winter probably increases developmental time of both eggs and larvae since it is well know that developmental time decreases with increasing temperature in many fish species (Blaxter 1969).

Behavioural observations showed that L. purpurea was less active when compared to L. lepadogaster, spending more time in resting activities (pause and sink). This again may be a consequence of the longer developmental period of $L$. purpurea, which implies spending significantly longer times in the water column. We hypothesise that during this extended larval period in the winter and early spring, larvae will likely encounter periods of low plankton availability. Spending more time in pause and sink behaviours is likely to be a better strategy for saving energy since locomotion and foraging activities are energetically costly to larvae (Kiørboe and Munk 1986).

Both species changed from a more 'saltatory' strategy to a 'cruise' strategy during development, approximately coincident with the beginning of notochord flexion. The pause-travel behaviour is probably associated to a saltatory strategy of searching for prey where the search for prey occurs only while pausing between swimming events (Browman and O'Brien 1992a, b). As larvae became more developed, most of their time was spent swimming, and they adopted a cruise strategy: the search for prey occurs while swimming (Munk and Kiørboe 1985). Additionally, foraging behaviour increased with development, which can be explained by an enhanced swimming capacity and visual acuity, which in turn will improve encounter rates and feeding success (Miller et al. 1993). The nature of the non-directed activities, such as sink and pause, is not straightforward (Rabe and Brown 2001). Sinking has been reported in other species, such as the snapper Pagrus auratus (Pankhurst et al. 1991) and the black sea bream Acanthopagrus schlegeli (Fukuhara 1987), and, like the pause behaviour, it has been interpreted as a resting behaviour.
The available descriptions for northeast Atlantic and Mediterranean larvae of Gobiesocidae are clearly incomplete (see Guitel 1888; Padoa 1956; Russel 1976). In particular, the two species described in this study have been mistakenly identified until very recently (Henriques et al. 2002). Consequently, the few larval developmental studies available for Lepadogaster (Padoa 1956; Russel 1976) need to be reassessed since developmental stages were all mixed into a single species and several misidentifications are likely to have occurred. For example, the descriptions made by Guitel (1888) for L. purpurea (previously considered as L. gouanii-see Henriques et al. 2002) were in fact larvae of L. lepadogaster. The available drawings clearly show the presence of ventral pigmentation and pigments on the lower jaw which are absent from L. purpurea, unmistakably ascribing these larvae to L. lepadogaster.

The correct identification of fish larvae is the basis for ecological and taxonomic studies of the pelagic stage of fishes (Leis and McCormick 2002). Errors in identification can lead to misinterpretations of ecological processes (Powles and Markle 1984) and studies like the present one are essential to improve our knowledge on the early life stages of marine fish.

Acknowledgements We would like to thank R. Lourenço for the illustrations and F. Gil for help during larval rearing. This work was supported by a PhD grant to AMF (SFRH/BD/21742/ 2005) and through the Pluriannual Program (R \& D Unit 331/ 94), financed by Fundação para a Ciência e a Tecnologia (FCT).

\section{References}

Allen LG (1984) Gobiesociformes: development and relationships. In: Moser HG, Richards WJ, Cohen DM, Fahay MP, Kendall AW Jr, Richardson SL (eds) Ontogeny and systematics of fishes. The American Society of Ichthyologists and Herpetologists, pp 629-636

Barlow GW (1968) Ethological units of behavior. In: Ingle DJ (ed) The central nervous system and fish behavior. University of Chicago Press, Chicago, pp 217-232

Beldade R, Pedro T, Gonçalves EJ (2007) Pelagic larval duration of 10 temperate cryptobenthic fishes. J Fish Biol 71:376-382. doi:10.1111/j.1095-8649.2007.01491.x

Blaxter JHS (1969) Development: eggs and larvae. In: Hoar WS, Randall DJ (eds) Fish physiology, vol. III. Academic, New York, pp 178-252

Borges R, Faria C, Gil F, Gonçalves EJ, Almada VC (2003) Embryonic and larval development of Gobius paganellus 
(Pisces: Gobiidae). J Mar Biol Assoc UK 83:1151-1156. doi: $10.1017 / \mathrm{S} 0025315403008415 \mathrm{~h}$

Breining T, Britz R (2000) Egg surface of three clingfish species, using scanning electron microscopy. J Fish Biol 56:1129-1137. doi:10.1111/j.1095-8649.2000.tb02128.x

Briggs JC (1955) A monograph of the clingfishes (order Xenopterygii). Stanf Ichthyol Bull 6:1-224

Briggs JC (1986) Gobiesocidae. In: Whitehead PJP, Bauchot M-L, Hureau J-C, Nielsen J, Tortonese E (eds) Fishes of the North-Eastern Atlantic and the Mediterranean. UNESCO, Paris, pp 1351-1359

Briggs JC (1990) Gobiesocidae. In: Quéro JC, Hureau JC, Karrer C, Post A, Saldanha L (eds) Check-list of the fishes of the eastern tropical Atlantic. UNESCO, Societas Europaea Ichthyologorum \& JNICT, Lisboa, pp 474-480

Browman HI, O'Brien WJ (1992a) The ontogeny of search behaviour in the white crappie Pomoxis annularis. Env Biol Fish 34:181-195. doi:10.1007/BF00002393

Browman HI, O'Brien WJ (1992b) Foraging and prey-search behaviour of golden shiner (Notemigonus crysoleucas) larvae. Can J Fish Aquat Sci 49:813-819. doi:10.1139/ f92-092

Fukuhara O (1987) Larval development and behavior in early life stages of black sea bream reared in the laboratory. Bull Jpn Soc Sci Fish 53:371-379

Gonçalves EJ, Almada VC, Almeida SP, Gonçalves DM, Repas M, Simões N (1996) Observations on the agonistic behaviour of Lepadogaster lepadogaster purpurea (Pisces: Gobiesocidae). J Fish Biol 49:367-369. doi:10.1111/ j.1095-8649.1996.tb00032.x

Gonçalves D, Gonçalves EJ, Almada VC, Almeida SP (1998) Comparative behaviour of two species of Lepadogaster (Pisces: Gobiesocidae) living at different depths. J Fish Biol 53:447-450. doi:10.1111/j.1095-8649.1998.tb00992.x

Guitel F (1888) Recherches sur les Lepadogasters. Arch Zoologie Exp Gen, 2ème série, 6:423-647

Hefford AE (1910) Notes on teleostean ova and larvae observed at Plymouth in spring and summer, 1909. J Mar Biol Assoc UK 9:47-48. doi:10.1017/ S0025315400073227

Henriques M, Lourenço R, Almada F, Calado G, Gonçalves DM, Guillemaud T, Cancela ML, Almada VC (2002) A revision of the status of Lepadogaster lepadogaster (Teleostei: Gobiesocidae): sympatric subspecies or a long misunderstood blend of species? Biol J Linn Soc 76:327-338. doi:10.1046/j.1095-8312.2002.00067.x
Hickford MJ, Schiel DR (2003) Comparative dispersal of larvae from demersal versus pelagic spawning fishes. Mar Ecol Prog Ser 252:255-271. doi:10.3354/meps252255

Kiørboe T, Munk P (1986) Feeding and growth of larval herring, Clupea harengus, in relation to density of copepod nauplii. Environ Biol Fish 17:133-139

Leis JM, McCormick MI (2002) The biology, behavior, and ecology of the pelagic, larval stage of coral reef fishes. In: Sale PF (ed) Coral reef fishes: dynamics and diversity in a complex ecosystem. Academic Press, San Diego, pp 171-199

Martin P, Bateson P (1993) Measuring behavior: an introductory guide. Cambridge University Press, Cambridge

Miller TJ, Crowder LB, Rice JA (1993) Ontogenetic changes in behavioural and histological measures of visual acuity in three species of fish. Environ Biol Fish 37:1-8

Munk P, Kiørboe T (1985) Feeding behaviour and swimming activity of larval herring (Clupea harengus) in relation to density of copepod nauplii. Mar Ecol Prog Ser 24:15-21. doi:10.3354/meps024015

Padoa E (1956) Uova, larva e stadi giovanili de Teleostei. Fauna e Flora del Golfo di Napoli Monogr 38:783-877

Pankhurst PM, Montgomery JC, Pankhurst NW (1991) Growth, development and behaviour of artificially reared larval Pagrus auratus (Bloch \& Schneider, 1801) (Sparidae). Aust J Mar Freshw Res 42:391-398. doi:10.1071/MF9910391

Powles H, Markle D (1984) Identification of fish larvae. In: Moser HG, Richards WJ, Cohen DM, Fahay MP, Kendall AW Jr, Richardson SL (eds) Ontogeny and systematics of fishes. The American Society of Ichthyologists and Herpetologists, pp 31-33

Rabe J, Brown JA (2001) The behavior, growth, and survival of witch flounder (Glyptocephalus cynoglossus) larvae in relation to prey availability: adaptations to an extended larval period. Fish Bull 99:465-474

Raventós N, Macpherson E (2001) Planktonic larval duration and settlement marks on the otoliths of Mediterranean littoral fishes. Mar Biol 138:1115-1120

Russel FS (1976) The eggs and planktonic stages of British marine fishes. Academic, London

Sponaugle S, Cowen R, Shanks A, Morgan S, Leis J, Pineda J, Boehlert G, Kingsford M, Lindeman K, Grimes C, Munro J (2002) Predicting self-recruitment in marine populations: biophysical correlates and mechanisms. Bull Mar Sci 70:341-375

Thresher RE (1984) Reproduction in Reef Fishes. T.F.H. Publications, Neptune City 